\title{
Morphology of starch from Araucaria angustifolia seeds treated by HMT and studied by SEM, AFM, and XRD
}

\section{Camila Delinski Bet ${ }^{1}$, Radla Zabian Bassetto Bisinella ${ }^{1}$, Tiago André Denck Colman ${ }^{2}$, Luiz Gustavo Lacerda ${ }^{1}$, Egon Schnitzler ${ }^{1}$}

\author{
1 - State University of Ponta Grossa, Ponta Grossa, Brazil \\ 2 - Federal University of Grande Dourados, Dourados, Brazil
}

\section{Keywords:}

Starch

Pinhão

Araucaria angustifolia

HMT

Morphology

Article history:

Received 12.06.2020

Received in revised form

24.08.2020

Accepted 27.12.2020

Corresponding author:

Egon Schnitzler

E-mail:

egons@uepg.br
DOI: $10.24263 / 2304-$

974X-2020-9-4-4

\section{Abstract}

Introduction. The aim of this study was to evaluate the main morphological and structural properties of native and modified starch by heat-moisture treatment (HMT) of "pinhão" seeds.

Materials and methods. "Pinhão" starch was extracted from seeds of Araucaria angustifolia. Amylose content was determined by iodine affinity. Humidity, ashes, protein and fats were determined by the Association of official analytical chemists (AOAC) methods. The microscopic techniques used were Scanning Electron Microscopy (SEM) and Atomic Force Microscopy (AFM). For structural evaluation of the granules, X-ray Powder Diffraction (XRD) was used.

Results and discussion. The "pinihão" starch extracted from aqueous methodology showed an amylose content of $26.3 \%$. The samples showed low moisture $(<8.5 \%)$ content as well as ash content $(<1.44 \%)$. By SEM and AFM, the largest average diameter $\left(\mathrm{d}_{\mathrm{a}}\right)$ was for untreated "pinhão" starch granules; 10.85 and $10.64 \mu \mathrm{m}$, respectively. The smallest granules were those treated with $10 \%$ humidity for $60 \mathrm{~min}$ and $120{ }^{\circ} \mathrm{C}$. The medium roughness $\left(r_{a}\right)$ studied by AFM increased according to HMT, from 321.68 to $470.06 \mu \mathrm{m}$, respectively. A reduction in the relative crystallinity $(\mathrm{Rc})$ was observed according to the HMT performed.

Conclusions. Round and oval shapes were found for the starch granules, with a flat face. Similarities were found in the mean diameter values $\left(\mathrm{d}_{\mathrm{a}}\right)$ between the techniques. The average diameter of the granules increased as humidity increased during the modification by HMT. The mean roughness $\left(r_{a}\right)$ increased with the HMT while the relative crystallinity $(\mathrm{RC})$ decreased. 


\section{Introduction}

Starch is a source of carbohydrates in nature. It is a natural biopolymer arranged as semicrystalline granules. Their main fractions are macromolecules of linear amylose and branched amylopectin. Due the abundance it is main source of carbohydrates in human diet. Starches can be obtained from several sources as roots, seeds, stems, etc.

"Pinhão" are the seeds from Araucaria angustifolia tree. This is a pine tree and grows in south of Brazil and other countries of south America. The seed contain 68-72\% starch which presents $26-28 \%$ amylose. Other compounds are proteins $(\cong 3 \%)$, lipids $(\cong 1 \%)$, soluble sugars $(\cong 2.4 \%)$ and fibres, minerals, phenolic compounds $(\cong 0.2 \%)[1-4]$.

Starch is useful in various industrial fields. However, in its native form has restricted limitations as low solubility in cold water, high viscosity, paste instability, etc. Talking in account this aspect, starch is frequently submitted to physical, chemical or enzymatic treatment, or their combinations in order to obtain some desirable properties to industrial applications [4, 5].

The heat-moisture treatment (HMT) of starches is a physical procedure that consists in add water upon starch (ratio $<35 \%$ ) and following by heating to temperatures above its gelatinisation temperature $\left(90-120^{\circ} \mathrm{C}\right)$ and for some time $(15 \mathrm{~min}-16$ hours). This hydrothermal modification is a technique considered natural and safe. It causes some features in starch granules, acts within the amorphous and crystalline regions and without destroying granular structure of starch granules [5-9].

The main microscopic techniques used in observation of starches are: optical microscopy - OM [2, 10, 11], scanning electron microscopy - SEM [5-11], atomic force microscopy - AFM [4, 12, 13]. In a previous review [14] has been reported the main characteristics (shape and size) of native starches from different sources obtained by SEM.

Many starches have been classified as A-type, B-type and C-type, by X-ray powder pattern diffractometry technique (XRD). This classification is in agreement with the position

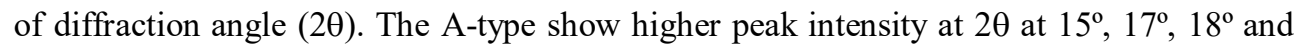
$23^{\circ}$; the B-type with higher peak intensity for angles of refraction $2 \theta$ at $5^{\circ}, 6^{\circ}, 15^{\circ}, 17^{\circ}, 22^{\circ}$ and $23^{\circ}$. The $\mathrm{C}$-type is a blend of $\mathrm{A}$ and $\mathrm{B}$ with peaks at $2 \theta$ at $15^{\circ}, 17^{\circ}, 22^{\circ}$ and $23^{\circ}$ [16]. On the other hand, with this technique it is possible to calculate the relative crystallinity of starch granules [11-13].

The "pinhão" is an unconventional source of starch, recognized for its nutritional value, and therefore encourages studies that enable its application. Thus, modifications can be tested to understand the behaviour of starch under different conditions employed. Physical modification, such as HMT, is widely valued as an environmentally friendly technology.

Therefore, the aim of this study was to evaluate the main morphologic and structural properties of untreated and modified starch by heat-moisture treatment (HMT) of "pinhão" seeds.

\section{Materials and methods}

\section{Materials}

The "pinhão" seeds were purchased from a popular market in the city of Ponta GrossaPR-Brazil. 
The starch was extracted in aqueous medium according the methodology described by Bet et al.,[1]. After extraction the starch was filtered and dried in an oven at $40^{\circ} \mathrm{C}$ by 24 hours and maintained in a desiccator up to constant mass.

\section{Methods}

\section{Amylose Content}

The amylose content of "pinhão" starch was performed in agreement with literature [1]. A potentiometric titrator (702 SM Titrino, Brinkmann Instr., NY) was used in determination of iodine affinity (IA). The procedure was performed in triplicate. The calculation of the amylose content, the IA value of starch was divided by the IA according the Equation 1:

$$
\text { Amylose }(\%)=100 \% \text { IA } / 0.2
$$

\section{Physicochemical Analysis}

The moisture, ash, protein and fat content were determined as AOAC methodology [19].

\section{Heat Moisture Treatment (HMT)}

The heat-moisture treatment (HMT) of starches were performed in the following way [11]: an aliquot of $100 \mathrm{~g}$ "pinhão" starch was divided in four portions with $25 \mathrm{~g}$. All samples were maintained in desiccator with anhydrous calcium chloride up to constant mass. Each sample show $8.1 \%$ moisture. One sample (untreated) was maintained in desiccator and labelled (a). Upon the second was added distilled water up to $10 \%$ (b); upon the third up to $15 \%$ (c) and upon the fourth up to $20 \%$, respectively. The samples (b, c and d) were homogenised and transferred to tree pressure flasks., sealed tightly with a hermetic lid. So, the flasks were maintained in an autoclave for $60 \mathrm{~min}$ at $120^{\circ} \mathrm{C}$. After this time, the flasks were opened and maintained in desiccator up to constant mass.

\section{Scanning Electron Microscopy (SEM)}

The micro-images of each sample were observed with high resolution using a Scanning Electron Microscope (model VEGA 3 Tescan, Czech Rep.) [10]. Initially, the samples were sprayed on a carbon tape and metalized with gold and so observed. It was possible to observe the shape and measure it size as well as the average diameter $\left(d_{a}\right)$ of a number of granules.

\section{Atomic Force Microscopy (AFM)}

Micro-images of "pinhão" starches were observed with high resolution using an atomic force microscope SPM 9600 (Shimadzu, Japan), by the non-contact method [8]. The starch samples were spread directly onto an adhesive tape fixed in the AFM sample holder. The micro-images of samples were observed with high resolution in 2D or 3D. Measurements and average diameter " $\mathrm{d}_{\mathrm{a}}$ " can be performed. With the scanning of surface of a set of granules it is possible to observe that this surface has irregularities. Thus, more or less smooth parts can be observed with protrusions and depressions. The measurement parameter that corresponds to the arithmetic mean of the absolute values of the distance ordinates $\left(\mathrm{y}_{1}, \mathrm{y}_{2}, \mathrm{y}_{3}\right.$, $\left.\ldots, \mathrm{y}_{\mathrm{n}}\right)$, divided by the number of measurements $\left(\mathrm{y}_{\mathrm{n}}\right)$ in the considered distance $\left(\mathrm{d}_{\mathrm{n}}\right)$, Figure 1 . 


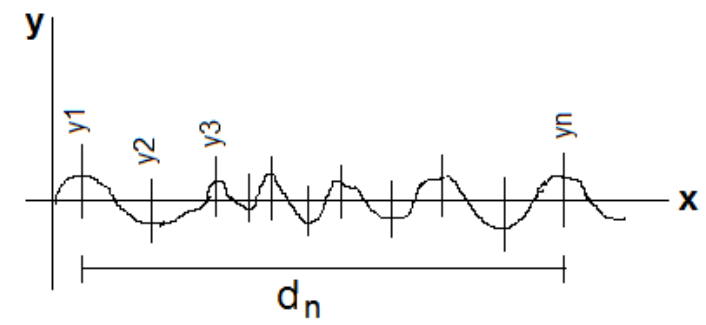

Figure 1. Measurements of average roughness $\left(r_{a}\right)$

The Equation 2 was used in the calculation of average roughness $\left(\mathrm{r}_{\mathrm{a}}\right)$ :

$$
\mathrm{r}_{\mathrm{a}}=\mathrm{y}_{1}+\mathrm{y}_{2}+\mathrm{y}_{3}+\ldots=\mathrm{y}_{\mathrm{n}} / \mathrm{n}
$$

\section{X-ray Powder Pattern Diffractometry (XRD)}

The X-ray diffractogram of each sample was obtained by the instrument Ultima IV (Rigaku, Japan). The following parameters were used: $\mathrm{Cu} K \alpha$ radiation $(\lambda=1.544 \AA)$, voltage $40 \mathrm{kV}$ and current $30 \mathrm{~mA}$; scanning speed $2 \mathrm{~min}^{-1}$, step 0.02, Bragg-Brentano geometry of $5^{\circ}<0<80^{\circ}(2 \theta)$. The main degrees of diffraction angles were observed and registered. The relative crystallinity was calculated in agreement with Equation 3, as described in literature $[7,12]$.

$$
R_{c}=A_{p} /\left(A_{p}+A_{b}\right) .100
$$

where: $\mathrm{R}_{\mathrm{c}}=$ relative crystallinity; $\mathrm{A}_{\mathrm{p}}=$ peak área; $\mathrm{A}_{\mathrm{b}}=$ base area

\section{Results and discussion}

The amylose content in the studied "pinhão" starch was $26.3 \%$. Similar values were found by Bello-Pérez et al. and Costa et al. [10, 12].

The moisture content for untreated and HMT modified starches were, $8.5 \%, 6.4 \%, 7.0 \%$ and $7.4 \%$, respectively.

The ashes were determined quantitatively and the values obtained were: $1.44 \%, 1.08 \%$, $1.39 \%$ and $0.85 \%$, respectively.

The protein $(2.12 \%)$ and fat $(0.44 \%)$ content were determined only for untreated "pinhão" starch, due to the changes that these macronutrients can undergo during HMT.

\section{Scanning Electron Microscopy (SEM)}

The microimages obtained by SEM are collected in Figure 2. 

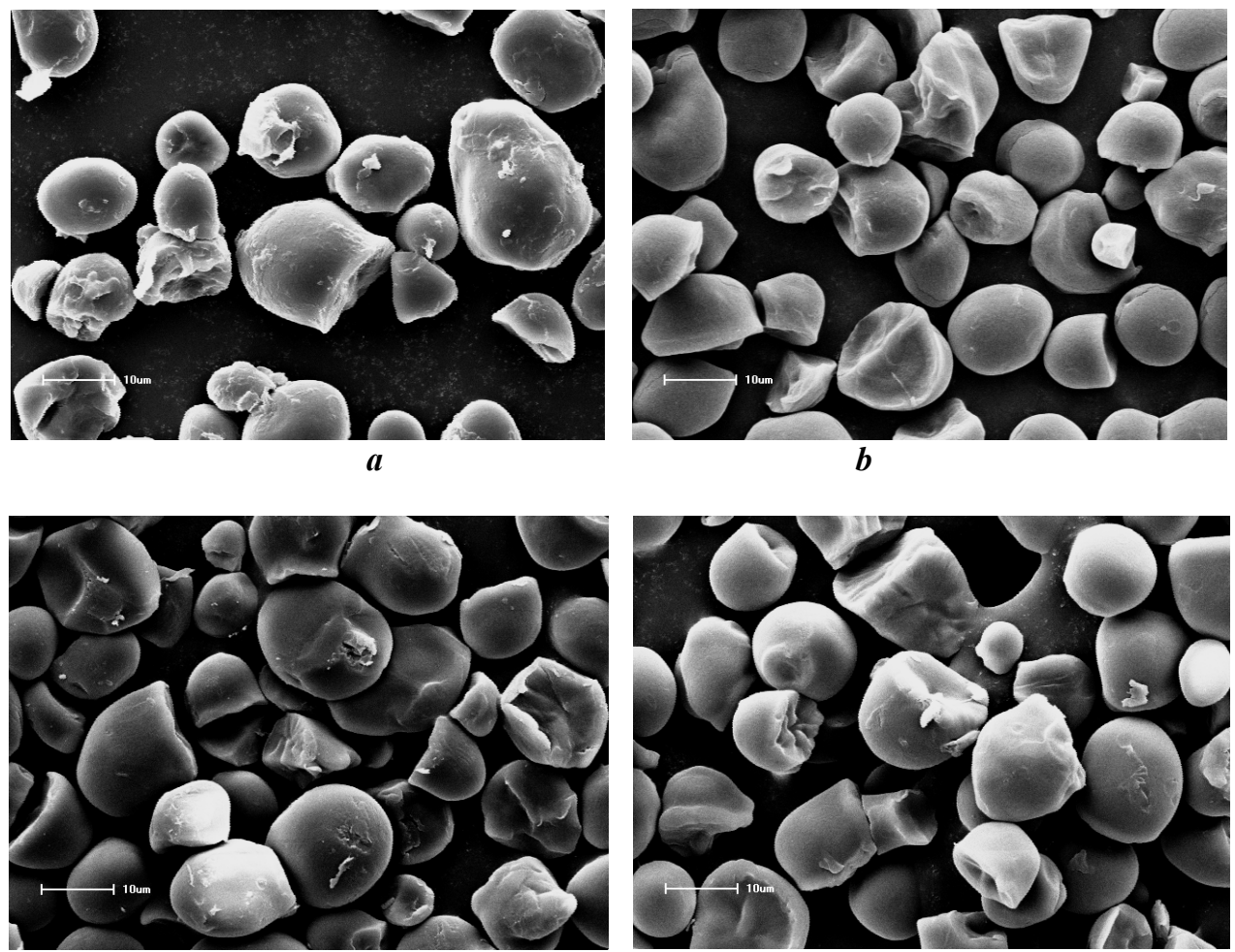

c

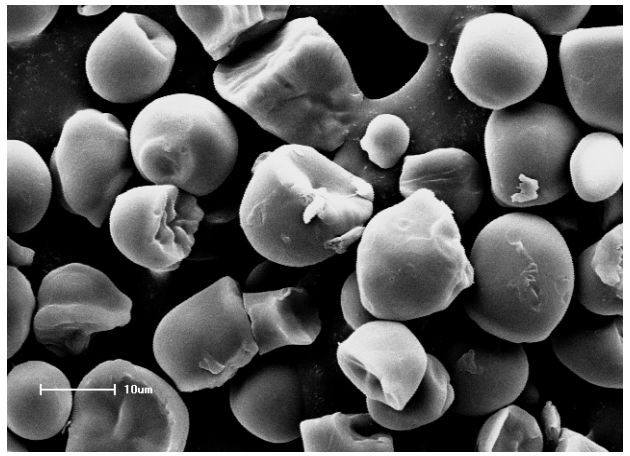

$d$

Figure 2. Scanning electron microscopy (SEM) of "pinhão" starch granules (a) untreated; $(b),(c)$, and $(d)$, treated by HMT (magnification $1200 \mathrm{X}$, bar $10 \mu \mathrm{m}$ )

According to the micrographs observed by SEM, the starch granules of the "pinhão" presented a rounded or oval shape, besides a flat face with some protuberances and depressions. No aggregation of granules was found in this investigation. Pinto et al., 2015, found aggregation in pinion starch granules when they were modified with moisture $\geq 25 \%$ [6]. The mean diameter of untreated and modified starches measured by SEM was $14.65 \mu \mathrm{m}$; the smallest granules had a diameter of $8.1 \mu \mathrm{m}$ and the largest $23.6 \mu \mathrm{m}$. Conto et al., 2011 [15], found values of $10-25 \mu \mathrm{m}$. The measurement of the average diameter $\left(d_{a}\right)$ by SEM is shown in Table 1.

\section{Atomic Force Microscopy (AFM)}

This tool was used as the contactless method (AFM-NC). The samples were spread directly on an adhesive tape fixed on the sample holder, and this was enough to immobilize the granules and avoid contamination of the starch surface. In Figure 3(a) scan size (24 x 24 $\mu \mathrm{m})$, a 3D acquisition image of the typical untreated "pinhão" starch granule demonstrating an oval shape is shown. On the surface we can see that it is relatively smooth with depressions and shallow grooves. Below Figure 3(b), the same 2D image of the starch granule with the measurements and next to the segments A-B, C-D, E-F, G-H that represents the height profile 
of the morphological surface. Considering the values found for the cross-section segments: A-B $=20.67 \mu \mathrm{m}, \mathrm{C}-\mathrm{D}=15.01 \mu \mathrm{m}, \mathrm{E}-\mathrm{F}=16.65 \mu \mathrm{m}$ and $\mathrm{G}-\mathrm{H}=19.46 \mu \mathrm{m}$, the average diameter $\left(d_{a}\right)$ found for this granule was $17.95 \mu \mathrm{m}$. However, at least three similar measurements must be made and the mean as well as a larger number of granules must be calculated. The graph of the section in Figure 3(b), right, corresponds to the measurement of the surface topography from different angles of the granule and is used with the software of the instrument to calculate the average roughness $\left(r_{a}\right)$, which was $302.4 \mu \mathrm{m}$ for this granule.

In Figure 4, with the resolutions of $120 \times 120,50 \times 50 \mu \mathrm{m}$, as in Figure 3, the 2D microimage of "pinhão" starch granules is represented. Here each segment A-B, C-D, E-F, G-H, displayed in a group of granules in each Figure, corresponds to a section measurement (in $\mu \mathrm{m}$ ) that can be used to calculate the average diameter of each granule. On the right side of Figure 4-b, the segments displayed correspond to the surface of the starch granules and are used to calculate the average roughness $\left(\mathrm{r}_{\mathrm{a}}\right)$, according to Equation 2.

(a)

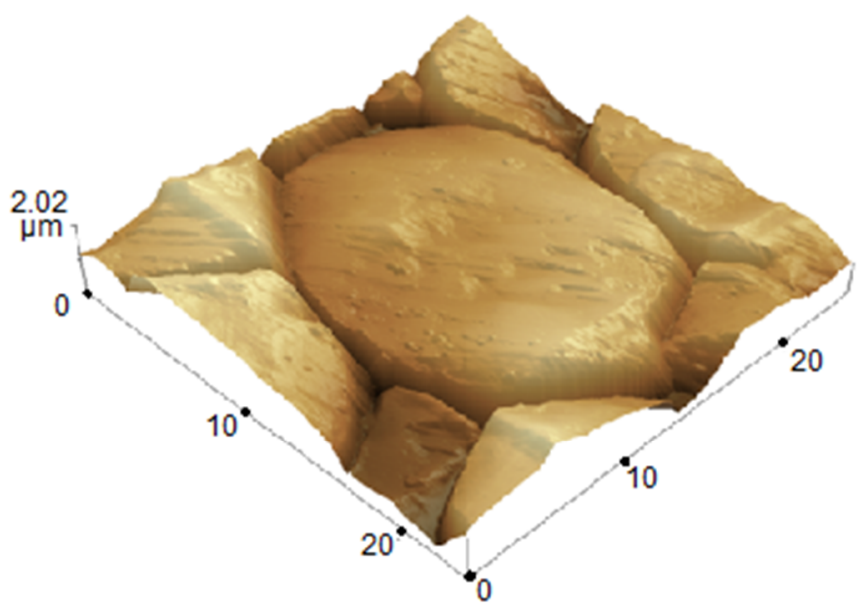

(b)

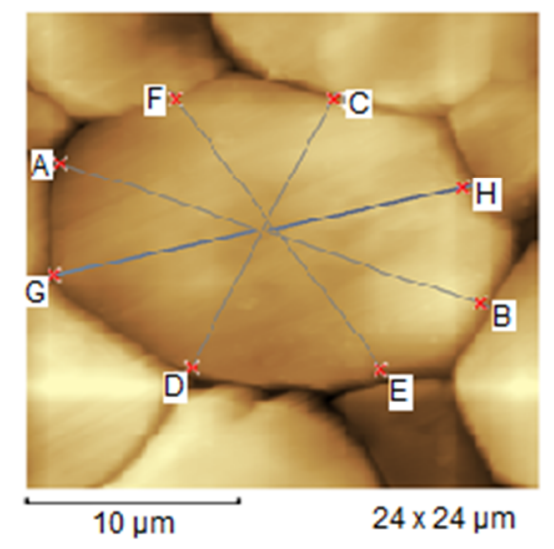

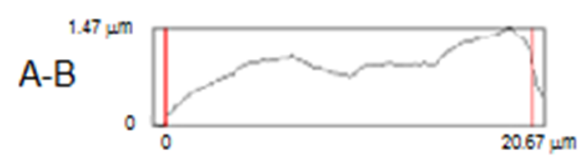
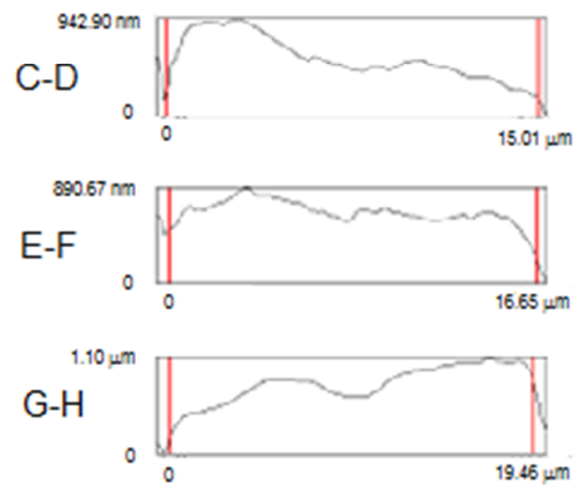

Figure 3. NC-AFM, 3D (a) and 2D (b) topographic micro-images of untreated "pinhão" starch (scan size $24 \times 24 \mu \mathrm{m}$ ), height difference $2.02 \mu \mathrm{m}$, and the cross section 
Since in a large amount of starch granules, they displayed different sizes, with each segment it is possible to measure different granules. Thus, other measurements are made in resolutions $20 \times 20,50 \times 50,80 \times 80,100 \times 100$ and $120 \times 120 \mu \mathrm{m}$ and in each one of them at least 4 measurements are made with 3 repetitions. Therefore, as shown in Figure 3, the measurements were made using the software of the instrument and it was possible to determine the average diameter $\left(d_{a}\right)$ of the granules and the average roughness $\left(r_{a}\right)$ of the surface granules

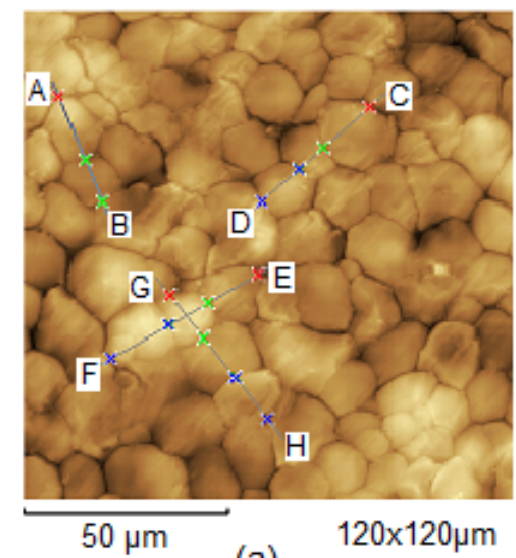

(a)

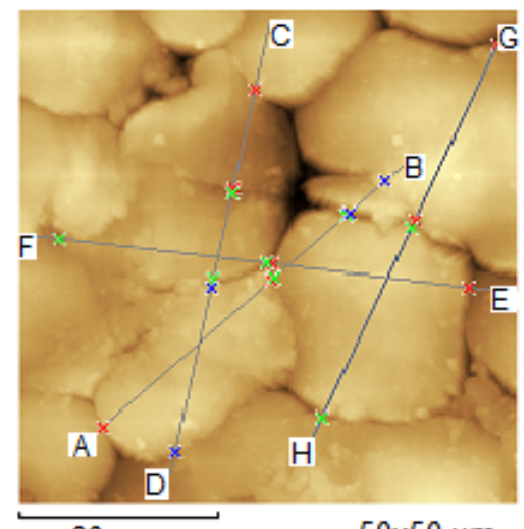

$20 \mu \mathrm{m}$
$50 \times 50 \mu \mathrm{m}$

$50 \times 504 \mathrm{~m}$

(c)

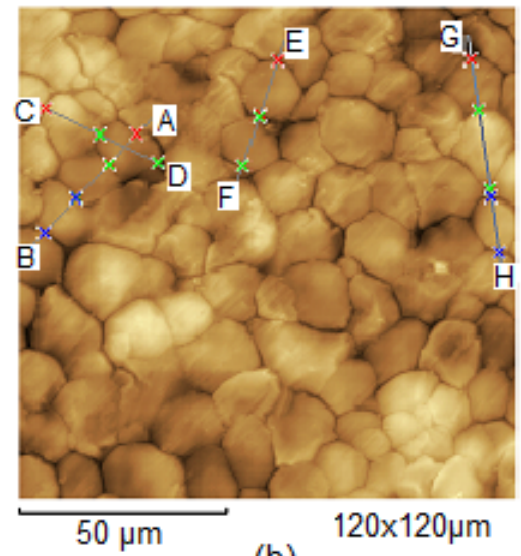

(b)

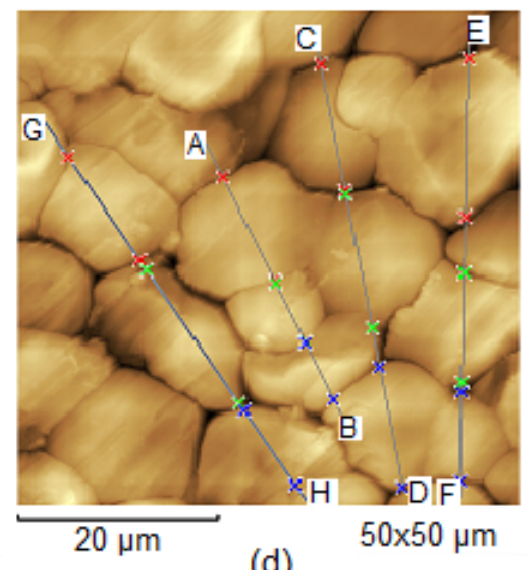

(d)

Figure 4: NC-AFM, 2D micro-image of untreated "pinhão" starch

(a) and (b) - scan size $120 \times 120 \mu \mathrm{m}$, height difference $4.29 \mu \mathrm{m}$;

(c) and (d) - scan size $50 \times 50 \mu \mathrm{m}$, height difference $2.61 \mu \mathrm{m}$.

In Figure 5 we can observe the 3D microimages of each sample of "pinhão" starch granules (untreated and after HMT with 10, 15 and 20\% moisture), under a scan size of 50 x $50 \mu \mathrm{m}$. 

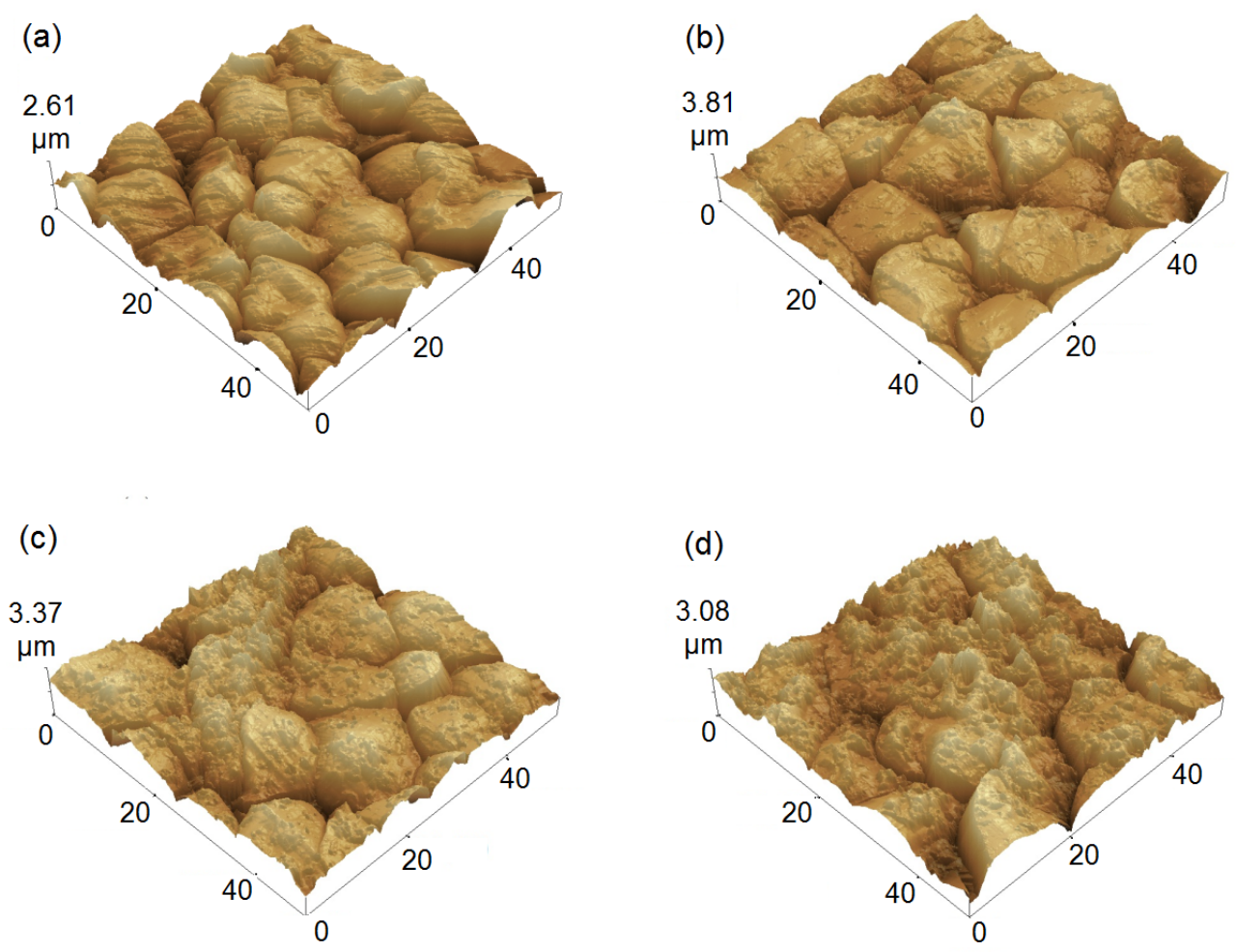

Figure 5. NC-AFM 3D micro-images of:

(a) - untreated "pinhão" starch granules;

(b) - "pinhão" starch granules with $10 \%$ moisture and after 60 min at $120{ }^{\circ} \mathrm{C}$;

(c) - "pinhão" starch granules with $15 \%$ moisture and after $60 \mathrm{~min}$ at $120{ }^{\circ} \mathrm{C}$;

(d) - "pinhão" starch granules with $20 \%$ moisture and after 60 min at $120{ }^{\circ} \mathrm{C}$.

Visually it is possible to verify that some changes occurred in the structure, mainly in the roughness, which increased proportionally with the increase of moisture in the HMT and heating for 60 minutes at $120^{\circ} \mathrm{C}$. The roughness was calculated according to Equation 2 and the values are represented in Table 1.

Table 1

Average diameter $\left(d_{a}\right)$ of "pinhão" starch granules measured by SEM and AFM and average roughness $\left(r_{a}\right)$ measured by AFM

(a) - untreated "pinhão" starch granules;

(b) - "pinhão" starch granules with $10 \%$ moisture and after $60 \mathrm{~min}$ at $120{ }^{\circ} \mathrm{C}$;

(c) - "pinhão" starch granules with $15 \%$ moisture and after $60 \mathrm{~min}$ at $120{ }^{\circ} \mathrm{C}$;

(d) - "pinhão" starch granules with $20 \%$ moisture and after 60 min at $120{ }^{\circ} \mathrm{C}$.

\begin{tabular}{|c|c|c|c|}
\hline Samples & $\mathbf{S E M}-\mathbf{d}_{\mathbf{a}}(\boldsymbol{\mu} \mathbf{m})$ & $\mathbf{A F M}-\mathbf{d}_{\mathbf{a}}(\boldsymbol{\mu} \mathbf{m})$ & $\mathbf{A F M}-\mathbf{r}_{\mathbf{a}}(\boldsymbol{\mu} \mathbf{m})$ \\
\hline (a) & 10.85 & 10.64 & 321.68 \\
\hline (b) & 9.56 & 9.29 & 426.15 \\
\hline (c) & 9.67 & 9.37 & 439.72 \\
\hline (d) & 10.48 & 10.26 & 470.06 \\
\hline
\end{tabular}

X-ray Diffractometry (XRD) 
The X-ray diffractometer pattern of untreated and modified "pinhão" starches is shown in Figure 6. The values of the main peaks in the diffraction angle $2 \theta$ are shown in Table 2. The analysis of these figures and values reveals that "pinhão" starches are semicrystalline solids, with main peaks (20) around 15, 17, 18 and 23o, characteristic of C-type.

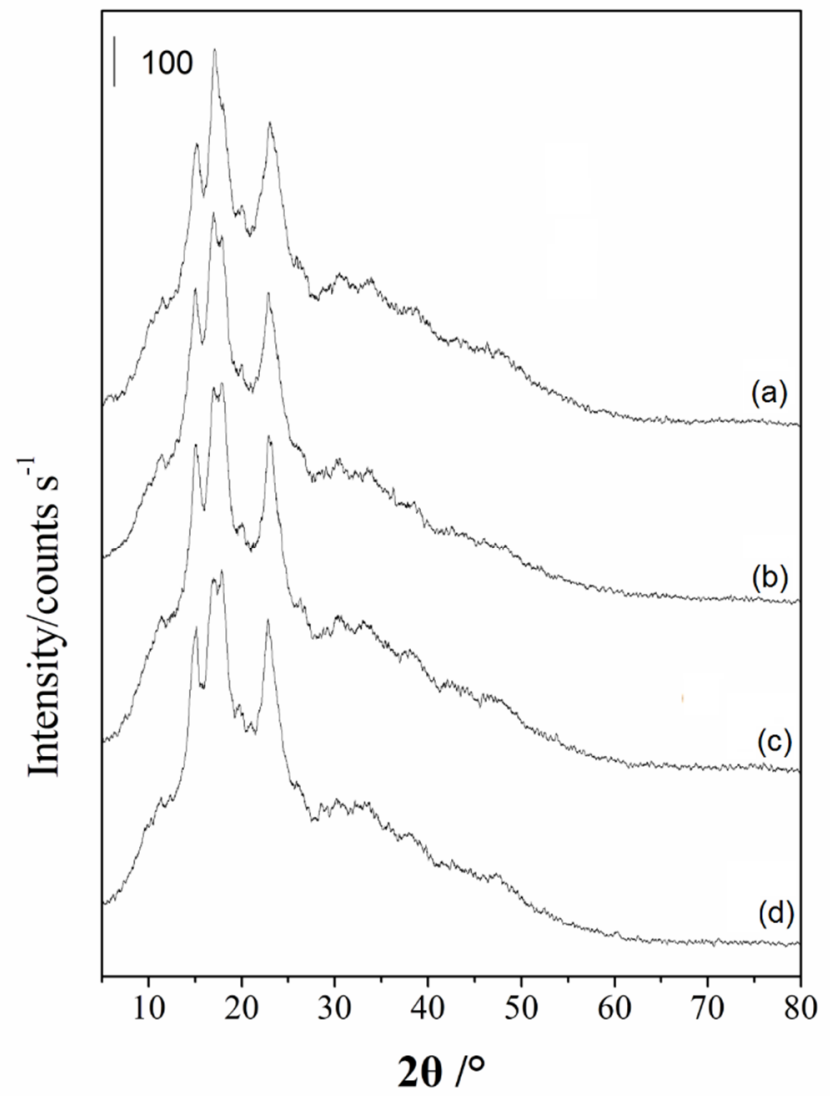

Figure 6. X-ray Diffractograms (XRD) of:

(a) - untreated "pinhão" starch granules;

(b) - "pinhão" starch granules with $10 \%$ moisture and after 60 min at $120{ }^{\circ} \mathrm{C}$;

(c) - "pinhão" starch granules with $15 \%$ moisture and after 60 min at $120{ }^{\circ} \mathrm{C}$;

(d) - "pinhão" starch granules with $20 \%$ moisture and after $60 \mathrm{~min}$ at $120{ }^{\circ} \mathrm{C}$.

According to the literature [17], the $\mathrm{C}$ type starch pattern is a semicrystalline polymorph characteristic of cereal and tuber starches, being a mixture of A and B polymorphs.

The relative crystallinity (RC) of untreated "pinhão" starch and modified HMT was calculated. The results obtained are in Table 2, and a decrease in RC with an increase in HMT was observed. This behaviour was observed by other authors [7]. The differences in values may be associated with the starch extraction method, which in this study was performed by aqueous methodology.

Table 2 
XRD values of: (a) untreated "pinhão" starch granules;

(b) "pinhão" starch granules with $10 \%$ moisture and after 60 min at $120{ }^{\circ} \mathrm{C}$;

(c) "pinhão" starch granules with $15 \%$ moisture and after 60 min at $120{ }^{\circ} \mathrm{C}$;

(d) "pinhão" starch granules with $20 \%$ moisture and after 60 min at $120{ }^{\circ} \mathrm{C}$.

\begin{tabular}{|c|c|c|c|c|c|c|}
\hline Sample & $\begin{array}{c}\text { Peaks } \\
(2 \theta)\end{array}$ & $\begin{array}{c}\text { Peaks } \\
(2 \theta)\end{array}$ & $\begin{array}{c}\text { Peaks } \\
(2 \theta)\end{array}$ & $\begin{array}{c}\text { Peaks } \\
(2 \theta)\end{array}$ & $\begin{array}{c}\text { Peaks } \\
(2 \theta)\end{array}$ & $\begin{array}{c}\text { Relative } \\
\text { crystallinity } \\
\left(R_{c}\right) \%\end{array}$ \\
\hline (a) & 15.09 & 17.05 & 18.10 & 18.75 & 23.30 & 20.94 \\
\hline (b) & 15.11 & 17.12 & 18.05 & 18.60 & 23.11 & 19.89 \\
\hline (c) & 15.23 & 17.10 & 18.01 & 18.66 & 23.00 & 19.02 \\
\hline (d) & 15.80 & 17.22 & 18.00 & 18.62 & 22.94 & 17.76 \\
\hline
\end{tabular}

\section{Conclusion}

Untreated and modified HMT "pinhão" starch granules were investigated by SEM and AFM microscopy techniques, and the results were similar between the two techniques. Some changes could be observed in the surface of the granules when analyzed by AFM, mainly in the average roughness that increases with heat-moisture treatment. The XRD technique allowed to determine the characteristics of type $\mathrm{C}$ and to calculate the relative crystallinity that decreased with the treatment performed.

Acknowledgements. The authors would like to thank to Brazilian Coordination for the Improvement of Personnel in High Level (CAPES) and Brazilian Council for Scientific and Technological Development (CNPq) proc. $n^{\circ} 307654 / 2017-6$ and 15589/2018-8.

\section{References}

1. Litvyak V. (2018), Size and morphological features of native starch granules of different botanical origin, Ukainian. Food Journal, 7(4), pp. 563-576.

2. Conto L.C., Plata-Olviedo M.S.V., Steel C.J., Chang Y.K. (2011), Physico-chemical morphological and pasting properties of pine nut (Araucaria angustifolia) starch oxidized with different levels of sodium hypochlorite, Starch-Stärke, 63, pp. 198-208.

3. Daudt R.M., Kullkamp-Guerreiro I.C., Caldera-Olivera F., Thys R.C.S., Marczak L.D.F. (2014), Determination of properties of pinhão starch: analysis of its applicability as pharmaceutical excipient, Industrial Crops and Products, 52, pp. 420-429.

4. Lawal O.S., Adebowale K.O. (2005), Physicochemical characterization and thermal properties of chemically modified jackfruit (Canavalia ensiformis) starch, Carbohydrate Polymers, 60, pp. 331-341.

5. Bet C.D., Oliveira C.D., Colman T.A.D., Bisinella R.Z.B., Beninca C., Lacerda L.G., Pumakahua-Ramos A., Schnitzler E. (2019), Aqueous extraction of organic amaranth starch and their by-products. Characterisation before and after degreasing, Journal of Thermal Analysis and Calorimetry, 138(4), pp. 2733-2749. 
6. Bicudo S.C.W., Demiate, I.M., Bannach, G., Lacerda, L.G., Carvalho-Filho, M.A.S., Ionashiro, M., Schnitzler, E. (2009), Thermoanalytical study and characterization of native starches of Paraná pine seeds (Araucaria angustifolia, Bert O. Ktze) and European chestnut seeds (Castanea sativa, Mill), Eclética Química, 34(1), pp. 7-12.

7. Cordenunsi B.R., Menezes W.E., Genovese M.I., Colli C., Gonçalves A.S., Lajolo F.M. (2004), Chemical composition and glycemic index of Brazilian pine (Araucaria angustifolia) seeds, Journal of Agricultural and Food Chemistry, 52(11), pp. 3412-3416.

8. Cordoba L.P., Bet, C.D., Schnitzler, E. (2015), Study by thermal methods of pinhão starch modified with lactic acid, Carpathian Journal of Food Science and Technology, 7(4), pp. 4147.

9. Ramos J.S., Barretti B.R.V., Almeida V.S., Ito V.C., Demiate I.M., Schnitzler E., Lacerda L.G. (2020), Thermal, structural, pasting properties and digestibility on green banana starch: combination of organic acids and heat moisture treatment, Brazilian Journal of Thermal Analysis, 9(1), pp. 1-12.

10. Pinto V.Z., Vanier N.L., Deon V.G., Moomand K., El Halal S.L.M., Zavareze E.R., Lim LT., Dias A.R.G. (2015), Effects of single and dual physical modifications on pinhão starch, Food Chemistry, 187, pp. 98-105.

11. Pinto V.Z., Vanier N.L., Klein B., Zavareze E.R., Elias M.C., Gutkoski L.C., Helbig E., Dias A.R.G. (2012), Physicochemical, crystallinity, pasting and thermal properties of heatmoisture-treated pinhão statrch, Starch/Stärke, 64, pp. 855-863.

12. Oliveira C.S., Bet C.D., Bisinella R.Z.B., Waiga L.H., Colman T.A.D., Scnhitzler E. (2018), Heat-moisture treatment (HMT) on blends from potato starch (PS) and sweet potato starch (SPS), Journal of Thermal Analysis and Calorimetry, 133, pp. 1491-1498.

13. Bet C.D., Oliveira C.S., Colman T.A.D., Marinho M.T.,Lacerda L.G., Pumacahua-Ramos A., Schnitzler E. (2018), Organic amaranth starch: a study of its technological properties after heat-moisture treatment (HMT), Food Chemistry, 264, pp. 435-442.

14. Bello-Pérez L.A., García-Suarez F.J., Méndez-Montealvo G., Nascimento J.R.O., Lajolo F.M., Cordenunsi B.R. (2006), Isolation and characterisation of starch from Araucaria brasiliensis: a novel starch for application in food industry, Starch-Stärke, 58, pp. 283-291.

15. Conforti P.A., Lupano C.E. (2007), Starch characterisation of Araucaria angustifolia and Araucaria araucana seeds, Starch-Stärke, 59, pp. 284-289.

16. Costa F.J.O.G., Leivas C.L., Waszczynski N., Godoi R.C.B., Helm C.V., Colman T.A.D., Schnitzler E. (2013), Characterisation of native starches of seeds of Araucaria angustifolia from four germplasm collections, Thermochimica Acta, 565, pp. 172-177.

17. Ribeiro L.S., Cordoba L.P., Colman T.A.D., Oliveira C.S., Andrade M.M.P., Schnitzler E. (2014), Influence of some sugars on the thermal, rheological and morphological properties of pinhão starch, Journal of. Thermal Analysis and Calorimetry, 117, pp. 935-942.

18. Lawal O.S., Adebowale K.O. (2005), Physicochemical characterization and thermal properties of chemically modified jackfruit (Canavalia ensiformis) starch, Carbohydrate Polymers, 60, pp. 331-341.

19. AOAC (2005), Official Methods of Analysis International, AOAC, Gaithesburg. 